\title{
A Pattern of Organization Management of Entrepreneurial Bugis Merchants Rice Trade in South Sulawesi, Indonesia
}

\author{
Ansar S.E ${ }^{1}$ \\ 'Lecturer, High School of Management Science Stim Tapim Maros, Indonesia
}

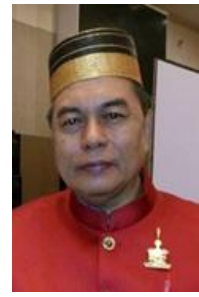

\begin{abstract}
This research analyzes the pattern of organization management of entrepreneurial Bugis merchants in South Sulawesi rice trade in ancient times. As for who became informants in this study was the Bugis traders who are still active and which is not a longer active trade of rice. This research is a descriptive analysis using qualitative approach through case studies, but the results of this study indicate that the majority of the Bugis merchants ever existed of his time and experience the ups and downs at the development time and intense competition, technology management and entrepreneurship. They are able to survive long is that implementing the principles of good management with i.e. planning, organizing, and monitoring the movement of the. In addition to that aspect of human resources play an important role in the process of developing the quality of thought, affecting every aspect of action, behavior in building interaction with each other both locally, nationally and internationally, so that this is causing the position of merchants Bugis have competitiveness and different characteristics with other merchants in the field first.
\end{abstract}

Keywords: Traders, Human resources, Entrepneurship, Competition, Businesemen.

Citation | Ansar S.E (2017). A Pattern of Organization Management of Entrepreneurial Bugis Merchants Rice Trade in South Sulawesi, Indonesia. Asian Journal of Social Sciences and Management Studies, 4(2): 76-82. History:

Received: 24. February 2017

Revised: 29 March 2017

Accepted: 20 June 2017

Published: 17 August 2017

Licensed: This work is licensed under a Creative Commons

Attribution 3.0 License (c))

Publisher:Asian Online Journal Publishing Group

\section{Contents}

1. Introduction

2. A Review of the Literature.

3. Method

4. Discussion

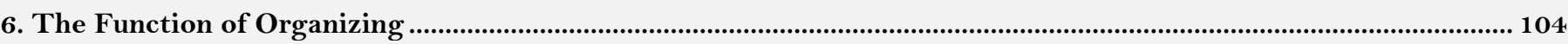

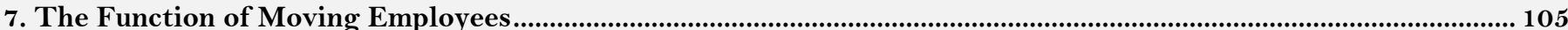

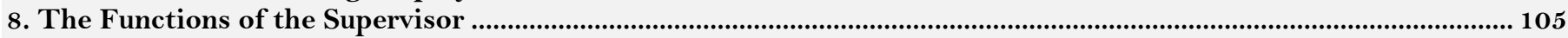

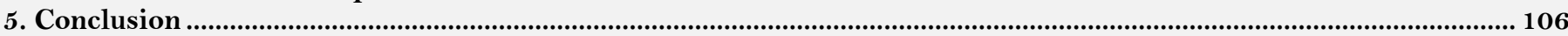

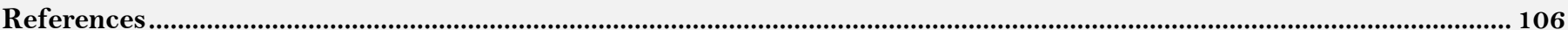

Transparency: The author confirms that the manuscript is an honest, accurate, and transparent account of the study was reported; that no vital features of the study have been omitted; and that any discrepancies from the study as planned have been explained.

Ethical: This study follows all ethical practices during writing. 


\section{Introduction}

The Bugis ethnic group is one of the ethnic groups in the homeland of Indonesia, The Republic unitary State which dwelt and flourished in South Sulawesi province. There are four ethnic groups in the province, which has a historical connection, namely Bugis, Makassar, Mandar and Torajan. The Bugis ethnic group has the largest population among all four tribes and many inhabited or lived in the region of the central part of South Sulawesi province, even spread throughout the County in South Sulawesi. In its development since ancient times, the ethnic Bugis not only flourished in South Sulawesi, but also they leave his hometown, go abroad, making a living in other provinces on this archipelago, are they as merchants, businessmen or merchants as well as other types of provesi.

Bugis merchants have been known in the past as a tenacious man, master cruise and trade in particular trade between the Islands in this archipelago and even out of the country, where one type of commodity at trading is rice. For the community of South Sulawesi, especially those of Bugis, the rice had a privileged position in the overall aspect of his life, because rice is the staple food for the majority of society Indonesia, and anyway most of the population of South Sulawesi work anyway in agriculture rice.

There are several aspects that support the development of the rice trade venture merchant Bugis in Sulawesi Selatan, from ancient times to the present, namely: first, the natural condition of South Sulawesi with ample rice makes this province as the largest food barn outside of Java Island. Secondly, the geographical location that is made up of lands and waters that make up the character of the people daring to sailing and trading. Third, the position of South Sulawesi amid the bustling cruise traffic so that commercial shipping passed and made the city of Makassar and Parepare as commercial airports are known for the reign of the Netherlands East Indies.

The triumph of Bugis merchants in the past was inseparable from the ability management in managing the entrepreneurial organization that is practiced. Rice trade between the island has evolved since the first, where the traders, businessmen or merchants using a sailboat in performing transport between districts and between the Islands, even to foreign countries such as Singapore, Malaysia and to the Philippines.

A pattern of organization management of entrepreneurial Bugis traders in trading rice, based on "a sense of trust, honesty and fairness". In an attempt to the achievement of the sense of justice among them, it makes to emphize the law when it was known as the "law of Cruise Amanna Gappa" with regard to the rules in the conduct of trade and shipping.

Merchants Bugis with the unsettled organization management pattern is able to make his business thrive in his time. One of the factors that support them can exist in the rice trade is the availability of ocean freight, though with homemade boats or the production people own a boat type such as Bugis Pinisi boats, lambo, and so on. The boats which are used as a means of sea transport, in order to haul their wares to other areas of the archipelago.

\subsection{The Problem}

How does the pattern of organizational management and institutional dynamics of entrepreneurial Bugis merchants in the trade of rice in Indonesia.

\section{A Review of the Literature}

G.R. Terry in Sarwoto (1991) put forward the notion of management, that Management is distinct process consisting of planning, organizing, actuating, controlling, utilizing in each both science and art and follow in order to Accomplish predetermined objectives. the basic element that is a source that can used to achieve the goal of management is man (humans), material (material), machine (machines), methods (work order), money (money). While the basic functions of management are planning (planning), organizing (organization), actuating (mobilization), and controlling (supervision).

The organization is a container two or more people working together for a specific purpose, with certain principles that underlie every activity, as in any business activity or trade developed by merchants since the first until now. Money in Sarwoto (1991) Organization as "the form of every human Association for the attainment of a common purpose (form any human cooperation for the achievement of common goals). G.R. Terry in Sarwoto (1991). Organisasi derived from the word "organism" is a structure with portions so integrated until their relationship to the whole. So an organization made up of two main parts, namely parts and relationships.

Steven (2001) The organization is a group of people (two or more) that intentionally unite in cooperation, as well as a working relationship to achieve the goals and targets previously set by the group. Or in other words that the organization is an alignment (system) of the factors of human and non-human. The organization is a social unit that coordinated deliberate, composed of two or more functions on a relatively continuous basis to achieve a series of goals and objectives.

Makmur (2010) Some opinions about the organization, namely:

(1) Thought organization as a container, that our thinking is oriented to collect a human activity. In this thinking organizations are viewed as static can perform various activities.

(2) Thought organization as a process, which we thought addressed to the organization is seen as something dynamic with various activities, creativity so that the objectives to be achieved it can be managed properly.

(3) organization thinking as an activity that is thought clear division of activities, meaning the implementation will give the maximum.

(4) Thought as a formal organization that form of organization whose formation is done formally by a leader or official who has the authority to do so.

(5) Thought as an informal organization, the organizational forms not be formal or in other words the official organization or nature is not fundamental to the formation based on agreements and guidance needs of its own members.

Bygrave (1996) argued that an entrepreneur is someone who earns opportunities and creating organizations to pursue them. The entrepreneurial process involves all the functions of the activities and actions related to the acquisition opportunities and the creation of the organization. 
Jhingan (1999) explains that entrepreneurship is hindered by social systems that reject creative ability. Customs strength, rigidity and suspicion on the status of new ideas and the desire intlektual, together create an atmosphere that is not fit for trial and new discoveries.

David (1980) suggests the need for a change, but our ability to perform corrective action is still hampered by a set of interests that are closely related are supported and endorsed by a vision of development that is based on false assumptions about the reality of our natural and social, Evereet and Floyd (1987). The process of social change consists of three successive stages: (1) Innovation, which is the process by which new ideas are created and developed. (2) Diffusion, is the process by which new ideas were communicated to the social system. (3) The consequences, namely the changes that occur in the social system as a result pengadobsian or rejection

Schumpeter in Pressman (2000) describes the business cycle, ie regular fluctuations experienced by the economy. Schumpeter, identified three different rotation or cycle occurring simultaneously. First, short-term fluctuations for about three to four years, the so-called "Kitchin Cycle" which were first discovered by Yoshep Kitchin. This rotation is associated with changes in business investment. The second cycle is associated with changes in business investment in plant and new equipment called "Juglar Cycle" for the first time discovered by Clement Juglar. Schumpeter argues that the expansion of the last four to five years are related to the company's desire to expand and modernize their capital equipment. But after largely be evolved and modern, they do not require much new investment, resulting in a reduction in spending on plant and equipment over the next four to five years. The third cycle is a cycle of long-term or "Kongratief Waves" (wave kondratif) about 45-60 years.

Latanro (1988) He argued that: (1) employers identify themselves with the company. There is no separation between ownership and business processing .; (2) rely on personal ability and tend not rate high ability of subordinates; (3) does not see his cooperation with employers Bugis as a practical necessity and a moral; (4) external relations paktor government deemed important to be used and (5) does not give much attention to the consumer.

This analysis is expected to have implications for the development of science or provide empirical support for the development of the theory of organizational management, entrepreneurship, economic anthropology. Apart from that also could have implications for government policy is to contribute ideas in formulating development policies entrepreneur (entrepreneur) in the rice trade.

\section{Method}

In this research, data collection was conducted at Bugis traders who pursue the rice trade. Samples in the classification in three phases: the reign of the Old Order, New Order administration and the post-New Order. The survey was conducted by in-depth interview to the respondents or informants to dig up information relating to the ins and outs of the Entrepreneurial organization management Bugis traders in the rice trade. Furthermore do it descriptive analysis approach with a qualitative analysis was conducted to decipher or describe patterns of business organizations developed management merchants Bugis in South Sulawesi rice trade in the face of competition in its time.

\section{Discussion}

\section{A. Patterns of Entrepreneurial Bugis Merchants Organization Management \\ 1. Planning Activities}

The planning function within an organization are extremely important in determining or setting the goals to be achieved. Rice trade venture merchant Bugis is inseparable on the need for careful planning, especially in planning rice stocks, and market analysis. Both of these activities is the determinant of a smooth business activities of trading or selling the rice among businessmen or merchants.

\section{2) Market Analysis}

Planning market will trade rice intended to market them, not always seamlessly implemented according to what they had planned, but sometimes experience changes according to needs of the market and the availability of capital, the means of transport. As for traders between the Islands in the past who relied on the transportation of a sailboat or motorboat was strongly influenced by the season. If the seasons and weather on the ocean allows for sailing, then they've left for transporting merchandise and when it is not possible, then they look for other marketing areas are younger.

Although rice to traders in the past aren't too concerned with planning on the basis of a modern administration, but they remain very membutukan planning more mature though unwritten, considering they are more at risk are higher than now. They are just using the tool transportation the sea depends on the season, different this time.

Although with limited means of transportation and communication, past merchants rely on his conviction based on experience that has felt that is not getting in trouble in the market berasnya, if it is to aim in the area such as on the island of Kalimantan, Central Sulawesi, Southeast Sulawesi and so on. Based on his experience, that in the area of the intended consumers are ready to buy, but the usual obstacles faced i.e. If on site marketing coincided with the influx of imported rice.

There is a distinguishing marketing planning in the rice trade between the Islands for merchants in the past with the present, namely the current mode of transportation either by land or sea are getting smoothly, kemunikasi business smoother because supported by advances in information technology, so that within a short time the merchants can know about market conditions, whereas in the past are not.

\section{B) Purchase/Rice Stocks}

The availability of rice stocks in the warehouse for a dealer inter island can affect the smooth delivery of the rice, because it requires good planning, to meet the target stock in the warehouse so that it can ensure the smooth delivery of the rice, and experienced no disruptions resulting from not tersediannya stock ready to be marketed. 
Activities in warehousing where rice stocks each year undergo fluctuations. Analysis of rice stocks is very necessary because it correlates with siqnifikan the uncertain harvest season. At the time of the harvest work, can cause a rich supply of rice from farmers and businessmen milling. For merchants is an encouraging potential because they can get rice from farmers at prices which are relatively inexpensive. But with cheaper prices, this does not mean automatically can buy more rice stocks, because it must be adapted to the capacity of the their warehouse

\section{C) Sales Targets}

The target sales volume is one part of a very important purpose, because any attempt to trade should ideally have a planning target sales increasing every year. In the modern business world, every business should have a steady marketing plan, because without planning, sales targets, the motivation of employers in developing his business is relatively low. The target into a measuring instrument to see the success of the rice trade venture merchant Bugis.

For the merchants in the reign of the old order until the middle of the reign of the new order, generally doesn't make planning sales targets in a written plan. They are not so easy to make changes to the planning of sales, because of the limited means of transportation and communication between the Islands at the time. Different current Merchants can only make changes to planning in a short time because of the support the expeditious transportation, warehousing and facilities complete better communication link at any time...

So merchants of the past in drawing up the sales planning are based on several factors: first, the market circumstances are appropriate estimates of the needs of the market demand. Second, estimates of the season in favor of cruise, the third, the success of the production and harvest for farmers. Current merchants in setting sales target more focus on the dynamics of the market, i.e. consumer demand and supply of rice as well as manufacturers of the present power potential, such as capital, warehousing and transport tools.

\section{D) Diversification and Enterprise Development in Other Sectors}

Development or expansion is part of the ideals of some employers, after the effort anyway developed then think to strive ahead with developing its business activities in other fields, such as the trading business the results of other Earth other than rice (tobacco, cloves, cocoa, coffee, and so on) and the results of the industry.

Bugis merchants during the rule of the old Order and the beginning of the new order, argues that trade in rice is very good, because rice is a very precious commodity needed by many people, because it once tried to trade rice no longer need to think of other types of businesses, so that the rice trade venture could develop, simply by acquiring rice trade venture it already can take family prosper.

Further efforts to develop trade in other commodities outside the rice, it needs caution employers because of the nature of rice is not like other commodities, where the commodity outside the rice it's easy going price changes that can cause harm on side trader, thus affecting the stability of trading business rice.

The younger merchants thus argues that planning for another, develop on other trade can support the increase in his business, as with the planning of employers can be more motivated to work hard and actively to seek business opportunities more profitable. Business focused not only on one field only, because when such business losses or congestion, then takes a long process/to bounce back. But if the effort of more than one type of commodity or product, when one of them suffered a slump, then there's still the other makes it possible to give a profit and sustain efforts to trade rice.

From the analyzer can be explained that there is a difference of views between the merchants with the age of the institution above 30 years with merchants who are still young (aged 20-year effort <). Older age, thus reluctantly left the rice trade to stop so entrepreneurs because they assume that the job of selling the rice, it was glorious and it takes a lot of people for his survival. So in addition to the benefit will also get a blessing and help the community practice in meeting the needs of anyway. They are convinced that his efforts will not be filed for bankruptcy, as long as people still make rice as needs anyway.

For merchants who are younger, it wants to diversify its efforts, because they believe that there is no guarantee against the stability of rice prices, which may cause harm to the rice entrepreneurs and can even cause bankruptcy. Factors of occurrence of inflation, changes in the value of the American dollar with the exchange rate of Rupiah, erratic season, rice policy by the Government (about the import of rice, the operations of the market) and so on, can be implicated on the instability of prices.

\section{E) Transportation}

Transport is one of the kind of supporting efforts to trade rice, both local and interstate trade of the island. Transportation by land needed to transport rice from farmers at the level of the purchasing Centre to the warehouse and from the warehouse to the port. Boat or motor boat ocean freight as required for transporting rice from the district to other districts and between the Islands. Some of the merchants transport goods and car has even had a boat or motor boat of its own.n addition to using the tool, the transport can also use the service provided by the freight marine transportation entrepreneurs such as PT. EMKL (Expedition Sea Ships). The names of companies known in the ocean freight business since the 1960 s to 2000 s is as follows:

Barru Regency (1) consists of: PL. Ilolo ivory, pl. Grace, km. Dates.

(2) The town of Parepare consists of: PT. Nurlina, ship name KM Nurlina PT. my hope in bloom, the name of the ship: KM my hope, PT. Lotus Flower, the name of the ship: km. lotus flowers, PT. Tanjung Selamat, the ship KM. Cape Merry, Sweet Cape, km. km. Tanjung Raya, PT Makarennu, the name of the ship: KM Light Merry \& KM Toro Sompe. PT. Makkalitutu, the name of the ship: km. Makkalitutu \& Teen Son, PT. Rusianto brothers (ethnic Chinese), the name of the ship: km. Samarinda Express 1, km. 2 Express, KLM Samarinda Lucky beautiful, Beautiful Spinach KLM, KLM Hibiscus bloom.

(3) In the Regency of Bone: Bone Malimpung \& pl. pl. Toberi, PLM Bone Rate, KLM Bone Kingdom (1980s present)

(4) The city of Makassar: km. Dilla Ocean $1 \& \mathrm{~km}$. Dilla Ocean 2, km. Multi Sejahtera, km. 7, Soraya KM Island Togia and so on. 
From the names of the company and the vessel as well as speedboat yet everything is recorded. The company expedition ships above sea, most of them featuring a boat or motor boat also have transportation by land or cars a truck, which supports smooth business EMKL.

As for the capacity or ability transport of the ship or boat used by merchants are as follows:

(1) Motor Sailboat (PLM) with the following characteristics:

- Load Capacity of approximately 4000 zak or high school with 100 tons

- Travel time for crossing into Kalimantan $10-15$ days

- Does not have room for passengers

(2) Sailing boat Motor (KLM) with the following characteristics:

- The charge Capacity of approximately $5000-7000$ Zak or 175 tons

- Travel time for crossing into Kalimantan $5-7$ days

- Does not have room for passengers

(3) Motorboat (KM), with the following characteristics:

- Load capacity of 10,000 - 12,000 Zak

- Travel time for crossing into Kalimantan 24-30 minutes

- There is room for a passenger charge.

In addition to using the services of the company ocean freight for private parties, as well as using the services of carriage owned by PT. PELNI, however the cost or the average cost incurred was higher compared to using motor boats. Motor boat belonging to PT PELNI also has limitations because the intended area based on routine which is already fixed and scheduled.

View merchant Bugis era of the 1990s against possession of sea transportation, such as his attitude towards the possession of means of transport by land, they aren't too worried about to have as a company asset, but more emphasis on utilizing existing transportation services offered by the companies transporting, good transportation by land or sea transport. Different merchant era in the 1970s argued that transportation is great for businesses were developed when the ability, because this business is indeed a direct contact and help smooth the rice trade is pursued so far.

\section{The Function of Organizing}

Organizing activities within a business activity is one of the important management functions are implemented, so that the business can run smoothly and accomplish company goals which have been set.

\section{A) Innovation (New Things in Marketing)}

According to Schumpeter (Bygrave, 1996) that an innovation is a new idea that is brought to market, where buyers are very enjoyable, so they expand purchases to include also a new product or service. Every successful innovation introduced by the company business, large or small, new or old, creating new demand for goods and services and would thus create new wealth

A new idea or innovation in any business activity is highly expected to give change to business development. Organizing the activities of new ideas or new findings is urgently needed in the effort to trade rice, as in producing good quality rice according to the wishes of consumers in the market, the way the packaging, labelling and marketing system.

As innovation was exemplified in rice trade efforts in the past, entrepreneurs tried two types of quality rice marketed in areas of Borneo Island, which is a type of mashed rice and rice milling machine result types. Both types have a different market share is namely to mashed rice allocated to consumer areas remote villages, while rice milling intended community of the city. Marketing ideas with two kinds of quality made in maintaining a kelanggenan effort.

The increasing role of competitors like Dolog and the emergence of PT. Pertani (Persero), which have the ability of capital and ownership of high capacity milling machines with higher quality rice, then getting sued employers or rice merchants to find new breakthroughs, in offset or compete with the PT. Pertani (Persero).

The presence of food in the system rice Dolog, undeniable benefits that have been felt by both the farmer, the consumer society in General and even by most Parties to the rice entrepreneurs. But if the views in depth with unconscious, thus happened to make few aspirations, motivation of entrepreneurs Dolog rice because as one of channelling food rice or rice, it means not too hard-won again the traders or entrepreneurs looking to rice market.

New ideas can be found by any employers or employees and other entrepreneurs. An entrepreneur can just modify the findings of others into similar models, but not the same as an example, as seen from the type of rice that is marketed by two or more employers, with the quality of rice of rice of the head are similar but not the same in the fragrance and so on.

Another example of the importance of organizing the findings from both the internal self or companies or outsiders, i.e. what has been developed by Pertani PT (Persero) by producing high quality rice head) which is packed with better packaging in maintaining the quality of the rice, did partner or coaching to groups of farmers, producers by providing capital assistance and other farming facilities, which can help farmers increase production. The result of the production of the farmers will be purchased by partners i.e. Pertani PT. (Persero) according to an agreement beforehand.

\section{B) Capital Resources}

Capital resources into its driving force of a business, therefore there should be the ability to organize all the potential, the potential sources and manage them. The function of organizing as a management function that can affect the course of the business, such as how organizer existing capital in conducting market orientation, determine priorities, options and get the credit loans. 
A businessman rice in determining target markets, should be carefully analysis against customer needs, competitors ' strengths and weaknesses, as well as predicting the expected sales target, so that it can allocate capital resources efficiently and effectively fit his needs.

Success in mastering the market depends on how to manage or organize existing capital resources, market orientation and in conducting the search for the appropriate market information. The orientation of the market in rice trade is important, because rice is the merchandise that is sensitive to the weather, the season and right so that the face of a relatively high risk of damage.

The importance the order of priority among the objectives of the market in rice, as entrepreneurs in the marketing of rice requires the precision of the destination market. Sometimes with particular consideration, as there is no order of priority, then the destination market of rice that had been ready to be transported to a certain area, suddenly shifted to another place, so sacrificing other existing partners, and can result in a breakdown in the partnership that's been built up all this time. This should not occur if there has been a market analysis and orderthe order of priorities.

In organizing capital resources, can be through banking, credit loans which are commonly employers of rice in areas related to the Bank Negara Indonesia (BNI) and Bank Rakyat Indonesia (BRI). Perrlu credit loan organized properly, since it is a loan that charged interest each month and the current year. If managed well will be beneficial to the development effort, however if not organized carefully, thus becoming a burden on companies that become obligations that may affect declining business conditions.

\subsection{Human Resources (Labor) and the Use of Technology}

Labor is the backbone of the company. In the rice trade labor marketing one of the keys to success, especially in trade between the Islands. Marketing labor should be organized in order to have performance in finding or creating new markets and take control of the market.

Duties and responsibilities in exercising and selling among merchants in ancient times on the interisland cruise travel, usually left up or appoint a responsible skipper in addition to the safety of the boat and any charge, as well as the sale of merchandise that is loaded particularly rice. In addition, there are given the authority to take another decision in the market of destination, if it thinks it can be profitable for them, or for the sake of the safety of the merchandise.

In addition to the skipper won the trust and authority, also made people trust to help skipper known as mustard greens. The mustard greens in addition to the duties and responsibilities towards the work in the boat, also helped business owners market their rice or other merchandise, such as go check the prices in various markets, wholesale traders and retailers as well as other tasks that are required in the area of destination.

Ownership and control of information technology is relatively still limited, so that it takes hard work among traders to seek its own areas of marketing that is more potential and promising advantages. It is therefore necessary the people trust with high responsibility.

A merchant must have the ability to organize the workforce, especially in the field of marketing because of this venture is the trading business. One of the unit's activities should be reinforced is part of marketing, i.e. must have the ability to monitor how the development of the price at any time in areas or other provinces, such as the area of already affordable marketing before. Besides doing telephone relationships with agents he knew rice.

The use of technology in trading rice is one of the functions which could affect the progress of the effort. With the use of technology, then the mashed rice as long as it is marketed is replaced by rice milling machine results. So did the packing with the use of sack burlap sack packaging usage was replaced with plastic.

\section{The Function of Moving Employees}

The activity moves or motivate the workforce in a given business activity is an important management functions including, in particular, the field of trade. An entrepreneur must have the ability to be able to motivate and move the workforce to do good work that has been assigned to him.

A merchant must have the ability of Bugis in moving its employees to work orderly and disciplined, capable of transferring innovation, whether self-created or other entrepreneurs on the inimitable. At globalization period increasingly competitive it needed the ability to transfer benefits and advantages other parties to be able to progressively improve the condition of his efforts.

The effort of moving employees to be more creative in finding innovation or novelty, as in purchase activity, the transport/transport, packaging, marketing, bookkeeping and financial administration that can stir up the progress of the business of the trade.

Can be exemplified how the merchant failed to Bugis in the past, in bookkeeping or administrative problems handling a relatively firm is still very traditional. Them with the traditional accounting model, i.e. rice circulation only records in and out of the warehouse, and the activities of the financial expenses associated with the purchase and so on, are done in a simple course. They are not able to show the full financial record keeping, each occurrence of a transaction, it cannot be demonstrated how much the real capital, their income as the income of the wife of the Director, as the holder of the Treasury, income of the child or the family who helped the profit level of effort and activity of its own.

\section{The Functions of the Supervisor}

The activities of oversight as a function of management is very important and necessary in the rice trade, because without strict supervision, then the entrepreneur is confronted with a market failure that led to the risk of loss.

\section{A Supervisory Employee}

Surveillance against power admnistrasi important do, because labor productivity in public administration and finance in the rice business activities, it is important to indicate whether the company was healthy or not. Labor 
productivity in public administration and finance in question here is, the ability of any administrative personnel in completing the task of recording bookkeeping or both in the field of

General and financial activities, such as correspondence, logging out, the amount of rice hutang-piutang entry, the position of capital, loans, profit and so on.

Bugis merchants very careful and pay close attention to the promise that has been agreed upon with the other party, so that the needed oversight in such matters. Keeping our promise in the rice trade venture is very important, because it concerns the credibility of an entrepreneur. In the past when an entrepreneur has Kaka, then the result against a loss of confidence in him, even though the confidante was a staple of capital for merchants, Bugis, in trying to specialize in trading between the Islands.

\section{B) Surveillance against the Quality/Quality of Rice}

Quality control against the rice trade is very important, because the quality of rice affects consumer tastes and can increase the thrust of the customers and satisfy the growing demand from consumers. Increased demand of rice traded ensures survival or smooth effort among merchants.

In everyday life, it seems that with the increase of people's income has been affected patterns of consume, particularly the demand for the fulfillment of the needs of an increasingly demanding quality rice, as rice as a staple that every day must be fulfilled. Therefore, employers already must anticipate the problems regarding the ever increasing demands of the desired quality of rice consumers.

In the 1960 s to the 1970 s with supplies or stockpiles of food (rice) are strictly limited to meet the needs of the community, so that any quality of rice traded can still enter the market, as required by the community. When that merchants not to choose quality rice which should be trading by choice's quality is still very limited.

Another case in the 1980 s to the present, with increased rice production, which makes the results of the South Sulawesi province as the granary of rice or rice-producing outside the island of Java, and the increasing quality of the processing technology of rice milling entrepreneurs owned and Pertani PT. (Persero), led to a growing various the type and quality of the products offered in the market. Good traders among retailers, or consumers have the opportunity to conduct the elections against various types of rice that will be bought and sold by traders and purchased by a consumer.

\section{Conclusion}

1. The rice trade Venture for Bugis merchants have experienced ups and downs, where known at period as a successful merchant, has even been able to penetrate the interisland trade using simple transportation tool i.e. a sailboat in the past. But along with the progress and development of the transport, communication and then shift has occurred so that they are able to survive and most of the rice trade venture to leave.

2. a business organization management pattern of Bugis in trading rice merchants in the old order and new order are still, in general, use traditional management pattern, they show the implementation of management functions are still weak, particularly on the function of planning and organization.

\section{References}

Bygrave, W.D., 1996. Entrereneurship. Jakarta: Binarupa Aksara.

David, K.C., 1980. Community organisation and rular development: A learning process approach. Public Administration Review, 40(5): 480511. View at Publisher

Evereet, R. and S.F. Floyd, 1987. Popularizing new idea. Surabaya: National Business.

Jhingan, M.L., 1999. Ekonomi Pembangunan dan Perencanaan, PT. Jakarta: Raja Grafindo Persada.

Latanro, 1988. Employers bugis an analytical painting. Dissertation Graduate Programme UNHAS, Makassar.

Makmur, 2010. Indonesia in the wake of global transformation: From nation-state to market-state? Indonesia Social Science Review, 1: 2.

Pressman, 2000. Lima Puluh Pemikir Ekonomi Dunia, Terjemahan Edisi Pertama. Jakarta : PT Raja Grafindo Persada.

Sarwoto, 1991. Fundamentals of organization and management. Jakarta: Ghalia Indonesia

Steven, R., 2001. Organizational behavior and management. Jakarta: Ghalia Indonesia. 